\title{
On the Translation of the Titles of Chinese Painting from the Perspective of Skopos' Theory
}

\author{
Shu Wei ${ }^{1, *} \&$ Yiduo Liu ${ }^{1}$ \\ ${ }^{1}$ School of Foreign Studies, Beijing Information Science and Technology University, Beijing, China \\ *Correspondence: School of Foreign Studies, Beijing Information Science and Technology University, Beijing, China. \\ E-mail: susiejournal@163.com
}

Received: March 19, 2015

Accepted: May 29, 2015 Online Published: June 9, 2015

doi:10.5430/wjel.v5n2p18

URL: http://dx.doi.org/10.5430/wjel.v5n2p18

\begin{abstract}
Traditional Chinese paintings are one of the most important parts of Chinese traditional art, which plays a significant role in promoting Chinese traditional culture to the world as well as enhancing cultural exchange programs with western countries. The thesis discusses the translation strategies for the titles of Chinese traditional painting through analyzing the main theories of the most typical advocators of Skopos, and provides different methods for cross-cultural translation from new perspectives. With the analysis of Skopos theory, the translation of traditional Chinese painting titles should follow the rules: the refinement of information, the transformation between reality and unreality, adding cultural information in the translation of title of Chinese traditional painting. With these three rules, the best effect of translation may be achieved, which can promote the communication between eastern culture and western culture.
\end{abstract}

Keywords: Skopos theory; Chinese traditional painting; title translation

\section{Introduction}

Research on the translation of the titles of novel, titles of films and names of places of interests in recent years has stimulated academic interest in Chinese painting. The purpose of this study is to focus on the translation of the titles of Chinese painting from the perspective of Skopos theory. Among various contemporary translation theories in Germany, Skopos theory is one of the most influential ones. The founder of Skopos theory, Hans Vermeer emphasizes the importance of social culture and the communicative function in 1970s. Simply speaking, this way of translation is based on the target-text reader, giving priority to the requirement of the function of translation. Different from many translators who proposed the rule of "faithfulness" and "equivalent value" which are all based on source text, Vermeer considered that the expression of source text is not the most important. He realized that translation can solve these problems existing between the culture of source text and target text. Even if the culture background of source text and target text is similar, the translator should take the method, purpose and result of translation into full consideration for achieving the best effect of the translation.

Reiss, another translator at that time, thought that translator should confirm the text-type, text variety and the style of the language at the very beginning. But for choosing translation method, her idea is more flexible than others. She did not exclude the way of translation, which focuses on source text. Also, she considered that different translation method fits different types of text. Different from Vermeer, she considered that the aim of translation was only decided by the translation initiator. Holz-Manttari put forward a more active theory-the translator's action theory, in which source text served communicative function and the target text.

According to all the above-mentioned researchers and conclusions about Skopos, the translation of the Chinese painting titles is the application of the theory from a multi-cultural background. Chinese traditional culture is a typical traditional art. In order to protect and promote Chinese traditional culture, the translation of the titles of Chinese painting plays a vital role. The major problem of the translation lies in the cultural and social difference between west and east. For example, the meaning of the same image is different even opposite in different cultures. Therefore the purpose of translation of the title of Chinese painting is to explain the Chinese culture to western 
audience so as to convey the messages, information and emotions contained in those Chinese works more accurately.

\section{Skopos Theory}

From the middle of the 20th century, a great breakthrough had been made in the study of western translation theories. Scholars who started to look at the translation phenomenon from different aspects had divided translation theories into various groups, including the Manipulation theory, the Poly-system theory as well as the Functionalist translation theory. Compared with other theories, Skopos theory is a new one. The word 'Skopos' comes from Greek which means goal and purpose. Vermeer used this word to express the purpose of translation or translation action. The definition of Skopos theory is translator should translate according to the purpose of translation action in the progress of translation (Christiane, 1997, p.35).

Translation is not merely a linguistic transferring activity due to different customs and values in different cultures. Firstly, the purpose of translation should be confirmed at the very beginning. Then, translator should translate according to the specific requirement, the purpose of translation and the reception situation of the target readers.

Skopos theory advocates that translation has its purpose and intention. It is also a kind of cross-cultural communication activity, which is based on source text. Translation is an intentional activity. On one hand, the intention could be understood to help those who speak different languages to communicate with each other. On the other hand, it means the intention of communicative essence. For instance, translation provides target receptors the original contents in the source text (Nord, 1997, p.27).

One of the most important principles in the translation progress is the Skopos of translation action. i.e. 'the result determines the way of translation'. There are three explanations of 'Skopos': 1) the basic purpose of translator; 2) the communicative purpose of target text; 3) The purpose which could be achieved through some specific translation strategies or methods. In general, the 'Skopos' means the communicative purpose of target text. So the translation initiator confirms the communicative purpose of target first. Because of special needs, the initiator should tell translator the reason of translation, the information of the target receptors, the environment of the translated text, the function of target text and some other information about translation.

Scholars of Skopos put forward a clear proposition. They considered that translator should adapt to the function of target text, communicative environment and the requirement of target readers from reader's point of view. Also, the translator should determine the translation strategy according to the intended function of target text, which helps the translation convey the original contents coherently and conforms to the norms of target language and cultural criterion. Besides, translator can revise and rewrite the original text appropriately. For special needs, Skopos theory provides possible ways for translator to apply translation strategies accordingly.

Skopos theory had shaken off the shackles of equivalent translation and functional equivalence theory. It emphasizes the subjective initiative of translator. It not only broadens the field of translation study, but also enriches the meaning of translation. Skopos theory makes translation into behavioral theory and intercultural communication.

In the early 1970s, Reiss proposed the criterion for translation criticism--the special purpose of translation action. At first, she believed that the translation should be equal to the original in form, content and communicative function. But after that, she found that it is impossible that target text is equal to original in translation sometimes. Thus, she considered that translator should give priority to function rather than equivalence. That is the foundation of Skopos theory. The goal of this theory is to pursuit the equivalence of the function between source text and target text, not the equivalence of the form of language.

Reiss recommended that we should divide text into three types based on the main features of the text, informative text, expressive text, and operative text. The function of Informative text is mainly showing information, knowledge, opinions, etc. Informative text emphasizes the content rather than the form. Its function is to deliver information and its language is logical. So translator should use simple and clear language to deliver the same concept and information in source text. Such text include: news report, business letters, the list of items, instructions, the patent description, treaties, official documents, literature, natural sciences and other technical fields (Munday, 2001, p.73).

Expressive text mainly shows the emotion and attitude from the sender to people and other things. Information plays a role of supplement but aesthetic factor is the dominant one. The linguistic style not only enhances the meaning of text, but also has the aesthetic effect. This kind of text has the aesthetic features and it emphasizes on the sender and the form of text. The way of translating expressive text is imitation which makes target text faithful to the source text and its writer. Because the most important thing is the effect of the mood and emotion of expressive sender, so it 
emphasizes on form of the text. This kind of text includes: essays, biographies, literature work, novels and various types of poetry (Munday, 2001, p.73).

Operative text stresses on affecting and persuading reader to take some action. The mission of the content and form of text is achieving the illocutionary effect of translation. The form of language, to some extent, shares some characteristics with the form of dialogue due to the reader-and-effect-oriented basis. So when we translate operative text, we can use editing and translation or other adaptive methods to attract readers (Munday, 2001, p.73).

In the specific translation, practically speaking, many texts do not belong to a single text type. That is to say, a text may have several functions simultaneously. Reiss called it 'composite type'. For instance, the function of reference book is providing information, so it belongs to information text; the function of poetry is expressing the emotion of poet, so poetry is the typical example of expressive text; the function of advertising is appealing reader, so advertising is operative text. However, in addition to the main function, poetry has the function of information and advertising may have the function of expression and information. For another example, biography may have the function of information and expression. Reiss emphasized that it is important to recognize the main function of text. Because delivering the main function of text is the decisive factor of measuring translation. The type of text determines the translation strategy to some extent. It determines the basic strategy but other factors will affect the strategy finally. Reiss created the term 'translation requirement'. She considered that the function of the text is important in target text. Due to the different translation requirement, the function of target text is different from the source text.

In 1989, Nord introduced the principle of function plus loyalty to Skopos theory. The 'function' in the principle of function plus loyalty means the aim of the influence from target text to the receiver of target language culture. The 'loyalty' emphasizes that translator should take the intention and expectation of all the parties of translation communicative behavior into consideration.

In the framework of Skopos theory, the purpose of target text is the most important criteria to choose the strategy of translation. The expectation of the reader of target text is the major factor for the function of target text. And the convention of target text culture determines the expectation of target text.

Loyalty means translator should be responsible for source language and target language. But it is different from fidelity which only means the relationship between the original and the translation. In translation action, loyalty is a moral and ethical concepts or professional ethics (Nord, 2001, pp.119). The responsibility of translator to other participants of translation depends on the loyalty. Thus, Nord tried to use a loyalty relationship between people to restrict the power of translator and the function of the original. At the same time, it can increase the discussion about the task of translation between translator and other participants. The translator should coordinate the difference between two cultures and consider various expectations of reader. It is difficult to understand expectations of reader exactly. So translator should choose translation strategy according to speculation and the limited feedback from client and readers. In the target language culture, the responsibility of translator is that readers can accept the translation. So, the translator should think about the expectations of the group of target language culture.

'Translational action' is the third stage of the development of functional translation theory in Germany. The theory was proposed by German Finn professional translator Holz-Manttari. This theory put forward new idea based on the Skopos theory. Holz-Manttari considered that translation is not simple transformation between word, sentence and text. It is a cooperation action based on expectation. The purpose is to break the cultural barriers. Holz-Manttari mentioned that in the theory: translation is a narrow concept. It is only related to the use of source text language. Thus, Holz-Manttari defined translation as 'translation action'. She considered translation action as a broad concept to express various intercultural communicative actions. The 'translation action' theory is similar to Reiss and Vermeer's idea. Differently, 'translation action' emphasizes on the communicative function in target language culture. In this theory, translation was explained to a kind of complex action to achieve some specific purpose. Holz-Manttari considered that the progress of translation is an action and the translator should analyze and understand the participants of translation and the environment. As a translational interactive form, the main content of translational action as follows: 1) translation is intentional interaction; 2) translation is interpersonal interaction; 3) translation is communicative action; 4) translation is intercultural action; 5) translation is text processing. Based on those points, we should consider more factors to make the target text more smooth and appropriate. The main purpose of translation action is people can cooperate and communicate with others effective in cultural barriers. This surpasses the traditional theory, which considers translation only as text (Nord, 1997, p.13).

Main contents: 
1. Translation is driven by its purpose, and its behavior guided by purpose. Translation is a purposeful action, which needs to consider the requirement of clients and readers.

2. Translation is a social behavior. It is not only a purposeful behavior, but it is also a communicative action and social interaction.

3. The action of translation belongs to the purpose of intercultural communication. Translation was regarded as the migration between different cultures of message-transmitter compounds, which includes text, picture, sound, and body language. Translator should consider human culture, especially the culture of target reader, the context of target language and other cultural factors which restrict translation.

4. Translator is the center of translation. From the original of information to the final receiver, translator is the expert in the translation. The task of translator is to decide whether, when and how to translate. Source text is one of information which translator can utilize. And translator only chooses the information which is useful to the purpose of translation.

'The cultural transformation' is different from the translation study based on experience. The cultural transformation means some foreign scholars transferred the translation from the transformation of two languages to the environment of target language in translation and some related restricted factors of translation. On this point, the functional translation theory has referential significance undoubtedly. It broke the argument between literal translation and free translation. And translation is purposeful intercultural action. The transformation between two languages is cultural collision. So translation is not only a simple transformation between languages. Actually, it is a special political, cultural and literary action in the society of target language.

\section{Features of the Titles of Chinese Painting}

The intuition of painting usually makes people ignore the language of painting. Before receiving any relative information, we can still fully enjoy a piece of painting from many perspectives and this kind of understanding is based on self-consciousness. That's why people always use their own criterion to measure the painting of other cultures before the background of painting was translated. If so, the understanding must be biased and parochial. The communication is easily to be changed from conversation to confrontation.

Compared with other kinds of literary forms, the title of painting has its special points. The title of painting lives in a special environment because it attaches great importance to the painting work itself. So when we translate the title of painting, we should consider all the relevant information of painting, which is also an important factor. In other words, the title works for the painting. When people enjoy paintings, no matter Chinese ones or foreign ones, the title of painting is undoubtedly a security and guidance to help audiences understand paintings better.

Last but not least, the title of Chinese painting has a strong color of Chinese traditional culture and also manifests a special way of language performance no matter the title is detailed or concise.

\section{Application of Translation Text in Skopos Theory}

\section{1 "Text Type" in Title Translation of Chinese Painting}

According to the text type theory of Reiss, we should discuss deeply the text type of the title of Chinese traditional painting first. Many scholars proposed that painting is a kind of language including visual language, image language and emotional language. The title of Chinese traditional painting has informative function, expressive function and operative function at the same time. Because the mission of title of Chinese traditional painting is delivering the relevant information of painting first, then, the title has aesthetic effect. Finally, the viewer can be infected by the title. At the same time, they can feel or agree with what the painter wants to express. Besides, painting itself has expressive function and operative function. So the informative function becomes the most basic and important function.

1) The Chinese title of a piece of painting is'舞风'(Wei, 2011, p.5). This painting shows a lotus waving in the wind. The Chinese title 舞风 has a kind of charm. If we translate it directly, the original meaning and charm of the title may be partly damaged. Therefore, from the perspective of informative function, the translation should focus on the theme 'lotuses'. So it is appropriate to translate it into 'lotus in a breeze'

2) The Chinese title of a piece of painting is '江南好'(Wei, 2011, p.3). In Chinese, the word '好' can be used in many situations. It usually means some advantages or something satisfying. But the interpretation would be much more 
detailed in the English context. In this painting, the painter wants to show the beautiful scenery of southeastern of China. So when we translate it, we should notice the core information 'the scenery'. So it is appropriate to translate it into 'the beautiful landscape in Jiangnan area'.

3) The Chinese title of a piece of painting is “浙南山水' $(\mathrm{Lu}, 1992, \mathrm{p} .12)$. The content of this painting work is beautiful scenery of the south of Zhejiang Province of China. In Chinese, people usually use mountain and river these two objects to stand for scenery. Considering from the perspectives of informative function, we should translate it into scenery rather than mountains and rivers. The word 'scenery' highlights the core information of painting----simple and powerful. So it is appropriate to translate it into 'scenery in southern Zhejiang province'.

4) The Chinese title of a piece of painting is “洛神赋图' (Wen, 2005, p.18). ‘洛神赋' is a famous romantic work by Cao Zhi who is a famous man of letters of Wei in three kingdoms period. Cao Zhi imitated the style of The Poem of Goddess and created the famous 洛神赋. The Poem of Goddess is about the king of Chu dreaming about the goddess of Wu Mountain. And the poem of Cao Zhi described that he was meeting with the goddess of the river Luo. We can see that Cao Zhi stands at shore and stares at the goddess of river Luo. Different countries believe in different god. So when we translate, we should translate '洛神'into 'goddess of river Luo'. So it is appropriate to translate it into 'rhapsody on goddess of river Luo'.

5) The Chinese title of a piece of painting is '秉烛夜游' (Wei, 2011, p.12). In the picture, a person is enjoying the scenery of courtyard, waiting for friends while holding the candlelight. So we should highlight the core information 'waiting for guests'. So it is appropriate to translate it into 'waiting for guests by lamplight'.

So when we deal with other translation like this, we should notice the refinement of core information.

\subsection{The Rule "Loyalty" in Title Translation of Chinese Painting}

According to the loyalty rule of Nord, we should consider the expectation of client and reader. It is no doubt that we should respect the intention of writer of source text. But the authority of source text is not absolute, unconditional and static. On the contrary, it is relative, conditional and dynamic. First, not all source texts are authoritative and sacrosanct. The authoritative text of a period or a culture may not be authoritative text after being translated into another period or culture. So we should confront with this fact that the existence of translated text depends on the existence of source text. But the existence of translated text depends on the existence of translated text. In the process of translation, we will lose something without the reference from the source context. Thus, the relationship between source text and translated text is coexistent and complement rather than the relationship between the authority and subordination. So translator should revise or add something according to different situations. And it is a good way to be loyal to writer, client and readers.

1) The Chinese title of a piece of painting is '文姬归汉图' (Wen, 2005, p.14). Cao Cao was very prestigious in north which makes the relationship between southern hun and Han became reconciled. Cao Cao remembered his friend's daughter lived in southern hun. And he wanted to bring her back. His friend's daughter was named Cai Wenji. After her father's death, a dogfight took place in Guandong area. People of Chang An was fleeing when soldiers of hun was looting. One day, they looted Cai Wenji to their king because Cai Wenji was beautiful and young. She lived in southern hun for 12 years. Although she was accustomed to live there, she missed her homeland very much. After that, Cao Cao brought her back. We can know that returning to homeland is significant to Cai. When we translate this title, we should consider the expectation of reader who may not know the relationship between Han and Cai. So we should translate Han into homeland which shows the significance of this painting. So it is appropriate to translate it into 'Cai Wenji returns to her homeland.'

2) The Chinese title of a piece of painting is '画壁图' (Wen, 2005, p.15). This painting shows simple and unsophisticated image of dharma. He wears red cloth and sits on the futon. His facial expression is tenacity and devout. Given that viewers may not know about Buddhism. It is not appropriate to translate it into 'facing the wall'. In order to consider the expectation of reader, we should translate this into 'meditation' which is the deep meaning of this painting.

3) The Chinese title of a piece of painting is “黄山云起' (Wei, 2005, p.7). The painting shows that there are some clouds around Huang shan mountain. The Chinese title is a kind of rhetoric which shows the dynamic beauty. But for different viewers, this way of expression may be a barrier of understanding. Considering the expectation of reader, we should translate the scenery directly. So it is appropriate to translate it into 'Huang shan Mountain among the clouds'.

4) The Chinese title of a piece of painting is '山寨尽染金' (Wei, 2011, p.25). This painting shows the scenery of a fortified mountain in the sunlight. The Chinese title is a kind of rhetoric. But the viewer of the target context may be 
confused for this way of expression. So we should consider the receptivity of viewer and explain that the gold represents sunlight. So it is appropriate to translate it into 'a fortified mountain village in a golden sunlight'.

5) The Chinese title of a piece of painting is ‘风柳摇春' (Lu, 1992, p.3). This painting shows the scenery of spring. The Chinese title is a kind of rhetoric which shows the dynamic beauty. The word '摇' links willow with spring. But the same word has different meaning in the target context. Considering the expectation of reader, we should translate it into 'betoken'. The booming scenery betokens spring. So it is appropriate to translate it into 'floating willow betokens spring'.

For the rule of loyalty, special attention should be paid upon the transformation between reality and unreality in translation. Only in this way may the target readers be more satisfied.

\section{3 "Translational Action" in Title Translation of Chinese Painting}

Translation is a practical activity in which the original meaning of the source text language is reinterpreted through another kind of language. The differences in cultural background, living environment and history between different nations are generated from their long terms development and evolution. And different environments lead to the culture difference. As we know, language is the component of culture. And language carries cultural connotation. People's understanding of the objective world reflects the exclusive differences of cultural backgrounds in different regions. Nevertheless, translation is the tool of solving difference to achieve the goal of cultural exchange and communication.

In many Chinese paintings, especially some literati painting, people use allusion to name the painting. Fine art is one of the categories of visual appreciation, the translated text should go with the image itself as a result. If the viewer don't know about Chinese culture, it is difficult for them to understand the painting.

For example, Chinese are accustomed to say 'we', but western people always say 'I'. The exclusive cultural spirit makes the social groups choose and restrict Chinese traditional arts in a more strict way. The allegedly people-oriented Chinese art is, to much extent, society-oriented, aiming to establish an integral emotion of the overall society or a class of people rather than that of individuals. Rebelling against traditions to emphasize on innovation is never what the Chinese artists uphold, for their creativity, on the contrary, happened to be the product of tradition heritages, which goes opposite to western painters, who are always guided by their subjectivity.

1) The Chinese title of a piece of painting is '双喜图' ( $\mathrm{Lu}, 1992, \mathrm{p} .8$ ). The magpie of this painting has the habit of keeping the field. One flies to help and the other tweet on the tree to demonstrate. Hare knows that the minacity of magpie is lower than falcon, so the hare stands and watches around. The connection between these three animals is dynamic and echoed. The painting was named after the two magpies. Because magpie represents noise in the west, people won't connect magpie with happiness. Now that we lose the luck of '双喜'. So it is appropriate to translate it into 'magpies and hare' to focus on the protagonist of the painting.

2) The Chinese title of a piece of painting is '郭巨埋儿' (Wen, 2005, p.37). In the painting, Guo Ju buries his son with his wife. The story of painting is that the family of Guo Ju was rich in the period of Jin. He divided the property into his two brothers after his father's death. He provided for his mother by himself. After that they became poor but his wife gave birth to a boy at that time. Guo Ju worried about the baby would influence that they could not provide for his mother. So he discussed with his wife to bury their son which can save food for their mother. The purpose of this story is to teach people to be filial. If we translate it into 'Guo Ju buries his son', the viewer can not understand it. So we should explain the purpose of saving food which can makes viewer understand the culture of China. So it is appropriate to translate it into 'Guo Ju buries his son alive to save food for his mother.'

3) The Chinese title of a piece of painting is “开门紫气幻云大’ $(\mathrm{Lu}, 1992, \mathrm{p} .6)$. The Chinese title of this painting shows the momentum of the scenery. Purple stands for bode. Before we are certain that purple stands for bode in all of culture, we should translate it into 'auspicious' to make it more directly to reader. So it is appropriate to translate it into 'auspicious atmosphere and magical clouds'.

4) The Chinese title of a piece of painting is '昭君和番' (Wei, 2011, 43). This painting shows Wang Zhaojun was on the road to marry with another nationality. The history is that Hu Hanye Chanyu was defeated by his brother. So he moved south and kept a good relationship with Han. He have gone to Han and asked for marriage to emperor Hanyuan. Wang Zhaojun was requested to marry for the purpose of harmonious kinship. Hun named her '宁胡闹氏” which represent the peace and thriving. '和番' means the dynasty of central plains use marriage to keep a good relationship with other nation or country. So it is appropriate to translate it into 'Zhao Jun married with princess of alien land' to highlights the cultural phenomenon. 
5) The Chinese title of a piece of painting is '梅妻鹤子'(Wen, 2005, p.6). This painting mainly shows crane and plum tree. The story is about Lin Fu of the period of Song. He had lots of knowledge but did not like fame and wealth at all. He is a hermit and doesn't have wife and children. He likes planting plum tree and keeping cranes. So people say that his wife and children are plum tree and crane. It is a metaphor which means lofty or hermit. And plum and crane represent lofty in Chinese. So it is difficult to understand it for foreigners. We should explain the information of lofty which can help people to understand it better. So it is appropriate to translate it into 'take a plum tree for one's wife and cranes for children-a lofty scholar.'

When we deal with like this in translation, we should notice the adding of cultural information, which can help people to understand Chinese traditional culture better.

\section{Conclusions}

As the saying goes, those belong to the nation belong to the world. Chinese painting should persevere in the Chinese feature and contain the traditional culture in painting works, which shows the wisdom and inspiration of Chinese people. In order to develop Chinese traditional painting, the translation of title is very important. A translator should be able to justify their choice of a particular purpose in a given translational situation. A good translator should know what to choose, what to omit, and how to strike a balance between loss and gains.

In this paper, the Skopos theory of Reiss, Nord and Holz-Manttari are introduced first. Then, the paper shows some translations of title of Chinese painting and analysis of these examples through Skopos theory. With the main idea of Skopos theory, some specific ways can also be adopted as translating strategies, which include the refinement of information, the transformation between reality and unreality as well as complement of cultural information. Besides, translator should have a clear realization of the translation of title of Chinese painting. Also, they should have a clear purpose in mind before actually do the translating.

\section{Acknowledgements}

The present research is sponsored by Beijing Higher Education Young Elite Teacher Project (YETP1507).

\section{References}

Christiane N. (2002). Manipulation and Loyalty in Functional Translation. Current Writing, 14(2), 32-44. http://dx.doi.org/10.1080/1013929X.2002.9678123

Christiane, N. (1997). Translating as a Purposeful Activity. Manchester: St. Jerome publishing.

Lu, Chuntao. (1992). Paintings of Lu Chuntao. Beijing: New World Press.

Munday, J. (2001). Introducing Translation Studies: Theories and Application. London: Routledge.

Newmark, P. (1988). A Textbook of Translation. London: Prentice-Hall.

Nord, C. (2001). Text Analysis in Translation. Beijing: Foreign Language Teaching and Research Press

Qiu, Jimu. (1991). Paintings of Qiu Jimu. Beijing: New World Press.

Vermeer. H. (2002). Skopos and Commission in Translational Action. London and New York: Routledge.

Wei, Shina. (2011). Chinese Contemporary Painting and Calligraphy: Greeting the Frankfurt Book Fair 2011 Series. Beijing: Bindings Bureau.

Wen, Jingen. (2005). Classic Chinese Figure Painting. Beijing: Heritage Press. 